\title{
讃岐国分寺本堂の昭和修理 \\ THE RESTORATION OF KOKUBUN-JI MAIN HALL, KAGAWA PREFECTURE, IN THE SHOWA ERA
}

\author{
三 浦 要 ${ }^{*}$
}

\section{Yoichi MIURA}

\begin{abstract}
The main hall of Kokubun-ji in Takamatsu City, built in the Late Kamakura Period, was designated as a national treasure under the Ancient Shrines and Temples Preservation Act. During repairing undertaken in the Showa Era (1941-1943), change of the building's original form was permitted. This paper discusses restoration that aimed to return the building to its original form, clarifying that the pitch of the roof after the remodeling was representative of the Edo Period, and was different from the original. It is also clear that the syumidan and zushi were made in the Kanbun Era.
\end{abstract}

\section{Keywords : National Treasures Preservation Act, Restoration of Historical Buildings, Change of original form, Report on restoration work, List of drawings, Main hall of Kokubun-ji 国宝保存法，文化財修理，現状変更，修理工事報告書，保存図，国分寺本堂}

\section{はじめに}

讃岐国分寺は高松市国分寺町国分に所在し，古義真言宗御室派に 属する寺院であり，白牛山千手院と号する。四国 88 か所霊場の第 80 番札所にあたり，昭和 27 年には讃岐国分寺跡として国の特別史 跡に指定されている ${ }^{1)}$ 。本堂は明治 37 年（1904）8月 29 日の「内 務省告示第五十七號」に「特別保護建造物ノ資格アルモノ」と定め られた ${ }^{2)}$ 。構造形式は桁行五間, 梁間五間, 一重, 入母屋造, 本瓦 莫である。『資料旧国宝建造物指定説明』には,

天平九年讃岐ノ国分寺トシテ草創セラレシ者ニシテ、寺伝行基 ノ開基卜称ス、再興年代明カナラサレトモ、鎌倉中期ノ者ナル カ如ク、向拝、㕌子、天井等多少後補ノ者アレトモ、様式手法 頗美ニシテ当時代ノ優作タルヨ失ハス

と掲載されている3）。建立年代は明らかではないが，建築様式から 鎌倉中期とみなされ, 向拝, 㕌子, 天井などが後補であることが知 られている。建立年代については，『国宝・重要文化財建造物目録』 に鎌倉後期（1275～1332）とある ${ }^{4)}$ 。指定後の主な修理には現状変 更が掲げられるが，報告書は未刊行となっている。解体修理は昭和 15 年度から昭和 17 年度にかけて実施され, 主任技術者は竹口富太 郎が担当し，総事業費が 67,665 円であった ${ }^{5)}$ 。

『国宝・重要文化財大全』には「内部に改造あり」と併記され6), 「須弥壇と天井まで達する大きな厨子は江戸時代の改造によるもの」 という指摘がある ${ }^{7)}$ 。さらに「内陣天井や屋根妻飾りは近世の改作 になるもので、屋根勾配なども当初とは異るらしい」8）「江戸時代 に幾度かの修理が行われ、屋根の形式（とくに屋根勾配）は中世と は異なっている」 ${ }^{9)}$ とある。建立年代は鎌倉後期であっても，屋根 勾配が当初とは異なっている。屋根の形態に関する現状変更では向
拝を撤去し, 復原の措置が講じられた 10)。須弥壇と影子は江戸時代 の改造によるもので, 内陣天井と妻飾も近世の改作とみられている。 明治 30 年の古社寺保存法の制定後は，解体修理がおこなわれ， 部材に刻まれた修理の痕跡が克明に調查され，創建以来の修理や増 改築の履歷が検討されるようになった。昭和 4 年公布の国宝保存法 では，現状の変更について主務大臣である文部大臣の許可を要する ことになった。ところが竣工後に部材が取り替えられて痕跡が残さ れない場合は，それ自体を検証することが困難となっている ${ }^{11}$ 。

本研究は近代の文化財修理に着目して修理の方針やその内容を明 らかにし，建立当初の建築様式，修理や増改築の履歴について検討 を加える一連の研究である ${ }^{12)}$ 。讃岐国分寺本堂の昭和修理では破損 状況や痕跡を調査し，修理や改造の履歴が明らかとなり，その成果 にもとづいて現状変更が許可されていたものと考えられる。ところ が報告書は未刊行であり，その詳細は明らかになっていない。昭和 修理をとりあげる重要な意義がここに存するが，これまで昭和修理 の解明が遅れていた原因のひとつは，資料上の制約であった。

本論が基礎資料とする松浦正一文庫の「國寶建造物國分寺本堂維 持修理報告書」（以下「報告書」と略記する）と題する原稿は，「香 川縣史編纂原稿用紙」に手書きで謄写され，最後に「昭和十九年十 二月八日竹口富太郎氏蔵原稿ヨリ謄写 奥村」と記されている ${ }^{13)}$ 。 「報告書」は 11 の章からなり，「國寶建造物國分寺本堂維持修理実 施設計書」という端書をもち,「工事ノ概要ヨ示スモノデ詳細八実施 二當リ慎重調査研究ノ上遺漏ナク遂行セルモノ」とある。「報告書」 は昭和修理において主任技術者を担当した竹口富太郎が私蔵した原 稿を, 昭和 19 年 12 月 8 日に謄写したものであった。「報告書」は 謄本ではあるが，その資料的価值は高いと判断することができる。 
表 1 讃岐国分寺本堂の昭和修理の経過

\begin{tabular}{|c|c|c|c|}
\hline 年月 & & 事 項 & 関倸者 \\
\hline 昭和13年 & 9月5日 & 大暴風雨により屋根の一部が破損 & \\
\hline & 10月5日 & 國寶修理二関シ實地御調査願 & 国分寺住職他 3 名から文部大臣宛 \\
\hline & 10月7日 & 國寶建造物修理二關スル件 & 香川県知事から文部省宗教局長宛 \\
\hline 昭和14年 & 10月24 27日 & 上田虎介技師の実地調査 & \\
\hline & 10月 & $\begin{array}{l}\text { 䅨川縣 國分寺本堂維持修理設計書 } \\
\text { 昭和四年十月調查! }\end{array}$ & \\
\hline 昭和15年 & 5月9日 & 國寶建造物維持修理二関スル件 & 文部省宗教局長加方香川県知事宛 \\
\hline 和16年 & 2月10日 & 解体修理工事が起工 & \\
\hline & 8月20日 & 技術官派遣願 & 国分寺住職他 3 名から文部大臣宛 \\
\hline & 8月29日 & 技術官派遣ノ件 & 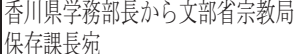 \\
\hline & 10月10日 & 「復命書 $]$ 國分寺本堂現状変更調査 & 伊藤久技手から文部大臣宛 \\
\hline & 10月13日 & 現状変更願 & 国分寺住職他 3 名から文部大臣宛 \\
\hline & & 國宝建造物修理二関スル件 & 香川県知事加文部省宗教局長宛 \\
\hline & 11月21日 & 国宝保存会で現状変更が許可 & \\
\hline & 12月1日 & 國寶建造物現状変更) 件依命通牒 & 文部省宗教局長から香川県知事宛 \\
\hline & 12月19日 & 設計変更及補助金增額願 & 国分寺住職他 3 名から文部大臣宛 \\
\hline & 12月24日 & 國寶建造物國分寺本堂修理二関スル件 & 香川県知事加文文部省宗教局長宛 \\
\hline & 12 月 & $\begin{array}{l}\text { 厂香川縣 國分寺本堂維持修理設計変 } \\
\text { 更書 昭和十六年十二五月調查」 }\end{array}$ & \\
\hline 和 18 & 8月31日 & 解体修理工事が完成 & \\
\hline
\end{tabular}

出典：「国分寺本堂修理工事精算書 1 件書類」と題する書類称り（大岡實博士文庫）

昭和修理は比較的詳細にあとづけることが可能となった ${ }^{14) 。 ~}$

本論は讃岐国分寺本堂の文献資料を可能な限り網羅し, 昭和修理 について考察を加えることが目的である。最初に昭和修理の経過と 現状変更の要旨を明らかにし, つぎに痕跡調査において解明されて いた増改築を検討し，最後に現状変更について考察を加える。

\section{1. 昭和修理の概要}

大岡實博士文庫には,「国分寺本堂修理工事精算書 1 件書類」と題 寸る書類の綴りがある ${ }^{15)}$ 。この書類の綴りは, 昭和修理の経過, 起 工後に現状変更が許可されていたことを明らかにする（表 1 )。

\section{（1）昭和修理の経過}

昭和 13 年 10 月 5 日付の「國寶修理二関シ實地御調査願」は, 国 分寺住職ほか 3 名から文部大臣宛に申請された。この申請をうけて 昭和 13 年 10 月 7 日付の「國寶建造物修理二關スル件」を, 香川県 知事が文部省宗教局長宛に提出した。実地調查願は, 「昭和十三年九 月五日ノ大暴風雨二依リ屋根一部破損致シ」とあり，昭和 13 年 9 月 5 日の大暴風雨により，本堂の屋根の一部が破損した。

『さぬき国分寺町誌』は, 香川新報の昭和 14 年 10 月 29 日付の 記事を引用し, 「本省上田技師の調査終る」「十二間四方の此の本堂 を先づ解体其筋の権威者をして再組立をほどこし建築當時其ま〉の 姿を止どめる事になつた」「總復舊費凡五萬圓と概算」とあり ${ }^{16}$, 上田虎介技師は屋根が破損した本堂の現地調查を担当していた。

昭和 15 年 5 月 9 日起案の文部省宗教局長から香川県知事に宛て た「國寶建造物維持修理二関スル件」には，「客年十月二十四日ヨリ 四日間本省嘱託上田虎介ヨ派遣致シタル處右修理設計書調製致シタ ルニ付」とあり, 上田虎介が作成したと考えられる「香川縣 國分 寺本堂維持修理設計書 昭和十四年十月調査」が添付されていた。

\section{（2）現状変更の許可}

昭和 16 年 8 月 20 日付の「技術官派遣願」は, 国分寺住職ほか 3 名から文部大臣宛に提出された。この派遣願をうけて昭和 16 年 8 月 29 日付の「技術官派遣ノ件」を, 香川県学務部長が文部省宗教 局保存課長宛に提出した。派遣願は「解体調查中二有之候本建造物
八後世大規模ナル改造ヨ加ヘタル痕跡习發見シタル」とあり, 解体 調査中に後世の改造の痕跡が発見されたことを記している。昭和 16 年 10 月 10 日付の「復命書」は, 伊藤久技手が出張調查の結果を, 文部大臣宛に「國分寺本堂現状変更調查」として報告した。

昭和 16 年 10 月 13 日付の「現状変更願」が，国分寺住職ほか 3 名から文部大臣宛に提出された。この変更願をうけて同日付で「國 宝建造物修理二関スル件」を，香川県知事が文部省宗教局長宛に提 出した。昭和 16 年 12 月 1 日起案の文部省宗教局長から香川県知事 に宛てた「國寶建造物現状変更ノ件依命通牒」には，昭和 16 年 11 月 21 日開催の国宝保存会で許可された現状変更が布達され，現状 変更の要旨が判明する。

昭和 16 年 12 月 19 日付の「設計変更及補助金増額願」は, 国分 寺住職ほか 3 名から文部大臣宛に提出された。この増額願をうけて 昭和 16 年 12 月 24 日付の「國寶建造物國分寺本堂修理二関スル件」 を, 香川県知事が文部省宗教局長宛に提出した。この書類には,「香 川縣 國分寺本堂維持修理設計変更書 昭和十六年十二月調查」が 添付されている。

以上の解体修理は「報告書」の「八，修理経過」によると，昭和 16 年 2 月 10 日に起工し, 昭和 18 年 8 月 31 日に完成した。当初は 昭和 18 年 7 月 31 日までに完成の予定であったが，「大東亜戦二遭 遇シ資材統制益々強化サレ労力又佛底シ」「農村ノ為义農繁期二八工 事八中止状態トナリ」とあって，延期された事情が明らかとなる。

\section{2. 昭和修理にみる建物沿革}

讃岐国分寺は天平 13 年 $(741)$ に聖武天皇の詔勅によって創立さ れたが，室町末期にいたる沿革が明らかでない。本堂は鎌倉後期に 西大寺流律衆が再興し，奈良時代の講堂の位置に建てられ，その際 に礎石が動かされているものと考えられている 17)。

\section{（1）基礎調査にみる床下地盤と礎石}

「報告書」の「五．各部ノ調查」には，土間が三和吅きのもので もなく, 敷瓦が張り詰められた形跡も発見されなかったとある。縦 横幅 1 尺 5 寸の布掘りをおこなうと， 1 尺 2 〜 3 寸の深さに平坦で 堅固な地盤があった。これは外部の地盤面へ天平時代の講堂あるい は現本堂の建立にあたって盛土されたものと考えられた。

痕跡については「側廻り及内部間仕切と同位置に地覆仕口穴を存 し、出入口方立の仕口溝が地覆まで延びてみる」とあり，建立当初 は土間式に計画されたが，床張りに改められたものと認められた。

礎石は自然石であり，石質と形状が天平時代の金堂跡の礎石と同 一のものであった。礎石の大きさは本堂に比較して大き過ぎるとあ り, 本堂は「天平時代建立ノ講堂焼失跡二幾分規模ヨ改メテ造立サ レタモノ」と推定している。昭和修理によって本堂は, 規模を改め て天平時代の講堂跡に建てられたとみなしている。

\section{（2）近世以前の讃岐国分寺本堂}

昭和修理において再用された文化年間の平瓦には，表面に陰刻さ れた瓦篦文字からつぎの銘文が見出され，講堂として建立されたこ とを伝えている。「報告書」の「三. 沿革」には, つぎのようにある。

今本堂者八往古ノ講堂也然二天正之頃兵二依テ回禄其ノ后寛文 之頃前大守松平讃岐守英公之諸伽藍悉御造営畢其後御代々之聖 主公雖御修造ス卜大二歳移テ無程破損ス又文化十三年頼儀公御 造砌焼之也 
表 2 讃岐国分寺本堂の昭和修理の現状変更等一覧

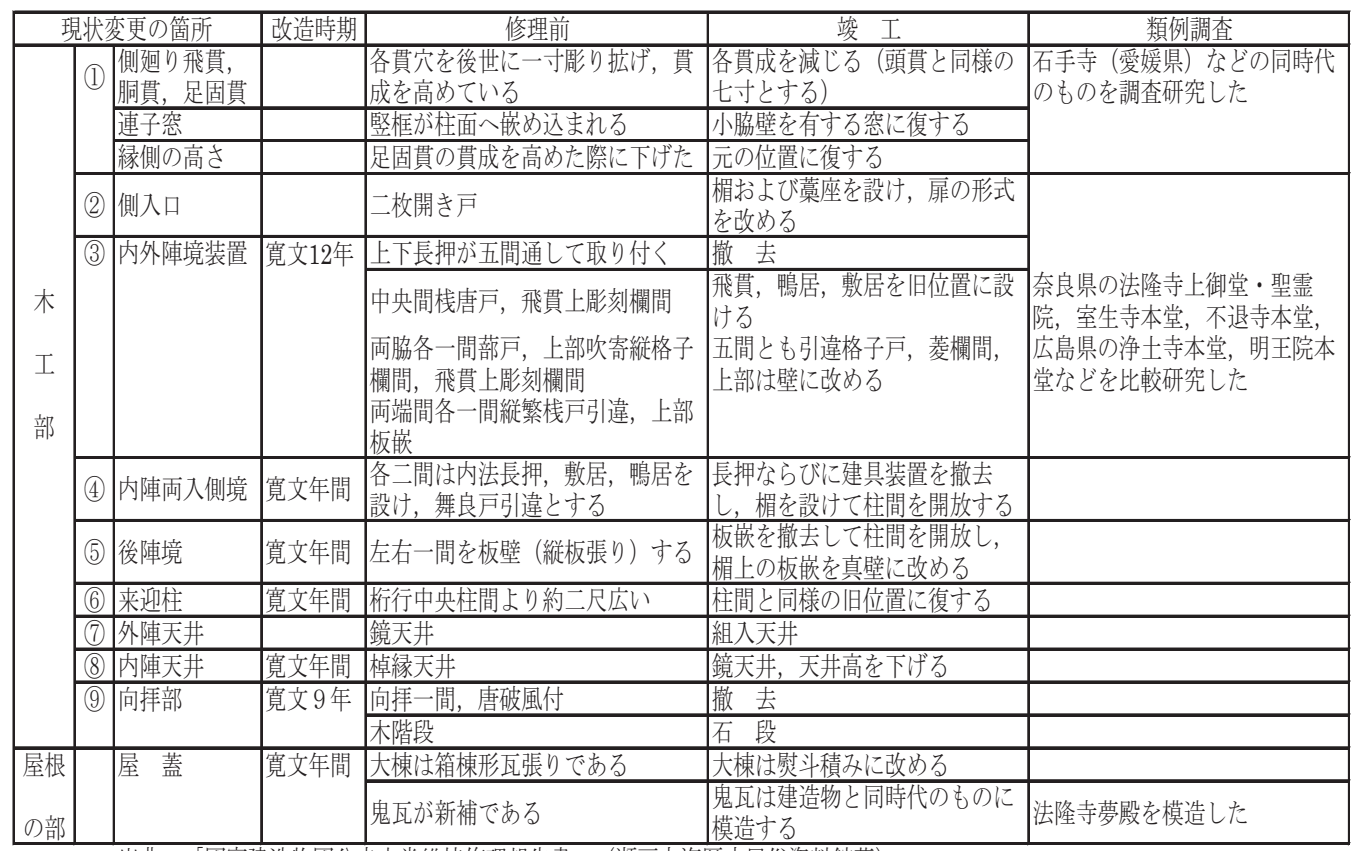

出典：「國寶建造物國分寺本堂維持修理報告書」（瀬戸内海歴史民俗資料館蔵）

天正 10 年（1582）に讃岐へ侵攻した土佐の長宗我部元親の軍勢 は, 讃岐国分寺を本陣として香西軍と戦った。その兵火に罹って寺 内の多くが烏有に帰し，旧講堂であったという現本堂のみが，その 難を免れたことを伝えている。

松平家の入国後は, 初代頼重が寛文 9 年（1669）に諸伽藍を造営 し，文化 13 年（1816）に第八代頼儀が本堂の屋根を莫き替えた。 それ以外には松平家の入国以前に生駒家の手によって修覆されたこ と, 享和 3 年（1803）に屋根を莫き替えたことが伝えられる。

\section{（3）昭和修理の発見物にみる修理歴}

「報告書」の「十一，発見物」は，昭和修理における発見物を「國 分寺天平年代瓦出土ノ説明」「瓦篦文字集」「墨書銘文集」の順に記 述している。天正 10 年以前の発見物には, 「瓦篦文字集」から文明 10 年（1478）と文明 12 年の年号が明らかとなる。本堂は文明年間 の瓦銘をもつ平瓦が使用されていたことになる。旧嵌板の用材は栂 であり，昭和修理まで野地板に転用されていたが，胴縁および小穴 の跡によって旧嵌板であったことが確認された。8枚の旧嵌板には 永正 10 年 (1513) の年号の墨書があり, 内陣飛貫に永正年間の墨 書が発見されていた。

「瓦䈯文字集」は 4 枚の丸瓦，3枚の平瓦，箱棟堅瓦の筑文字に 寛文 9 年の年号がある。「墨書銘文集」をみると， 3 枚の嵌板の用材 は松板で，内陣天井を寛文年間に高めたところに使用されていた。 来迎板壁太鼓張胴貫の 2 箇所には, 寛文 9 年の年号の墨書があった。 寛文年間の造営は, 昭和修理における発見物の瓦銘と墨書から, 屋 根が莫き替えられ，内部を改造していたと考えられる。

「瓦䈯文字集」には文化 13 年の年号が唐草瓦の 1 枚, 平瓦の 3 枚，丸瓦の 1 枚，巴瓦の 3 枚を含む 10 枚にあった。これらの瓦銘 は，文化年間に屋根莫替工事がおこなわれたことを示している。 昭和修理では寛文年間と文化年間の発見物が確認されており，寛 文 9 年の造営から昭和修理が開始された昭和 16 年までの 272 年間
に，根本修理がおこなわれていなかったものと考えられる。

\section{3．昭和修理の現状変更の要旨}

現状変更は昭和 16 年 11 月 13 日に諮問され，11 月 21 日開催の 国宝保存会で許可された。変更の要旨は「国分寺本堂修理工事精算 書 1 件書類」から判明するが，『清交』（第 19 号）の「國寶建造物 現状變更説明 昭和十六年十一月」には，変更の要旨に加えて理由 説明が掲載されている 18)。現状変更の要旨は,つぎの通りであった。

一、側迴飛貫、胴貫、足固貫の各貫成を減じ、之に伴ひ各連子 空及縁を舊規に復せんとす

二、側廻り扉口に楣及葈座を設け、且扉の形式を改めんとす

三、内外陣界を舊規に復せんとす

内陣前面五間の後補の間仕切装置即、

中央間栈唐戸、飛貫上彫刻欄間

その両脇間各一間蔀戸、上部吹寄縦格子欄間、飛貫上彫刻欄間 両端間各一間縦繁栈戸引違、上部板嵌

各両上下長押附

なるを孰も撤去し、飛貫、鴨居、敷居を舊位置に設け、五間共 引違格子戸、菱欄間、上部壁に改めんとす

四、内陣両側各二間内法長押附舞良戸引違なるを、長押並に建 具装置を撤去し、楣を設け各柱間を開放に爲さんとす

五、後陣左右各一間の板嵌を撤去して開放となし、楣上板嵌を 壁に改めんとす

六、内陣後柱中央二本を舊位置に復せんとす

七、外陣鏡天井なるを組入天井に復せんとす

八、内陣猿煩天井なるを鏡天井に改め、且高さを低めんとす

九、向帱を撤去し、之に伴ひ同所の木階段を石階段に改めんと 寸 
現状変更(5) 後陣境の各一間は板嵌を撤去し，柱間を開放する。

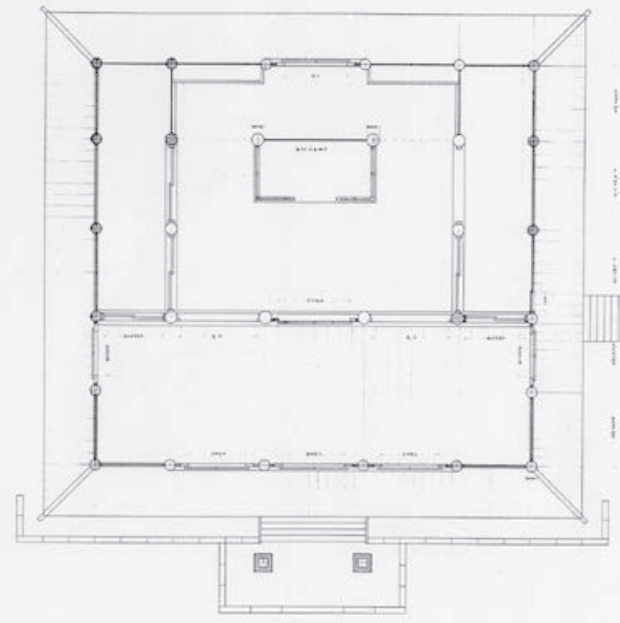

現状変更(6) 来迎柱は桁行中央柱間より約二尺広く，

柱間を桁行中央柱間と同位置にする。

図 1 修理前平面図（出典：『国宝・重要文化財実測図集』）

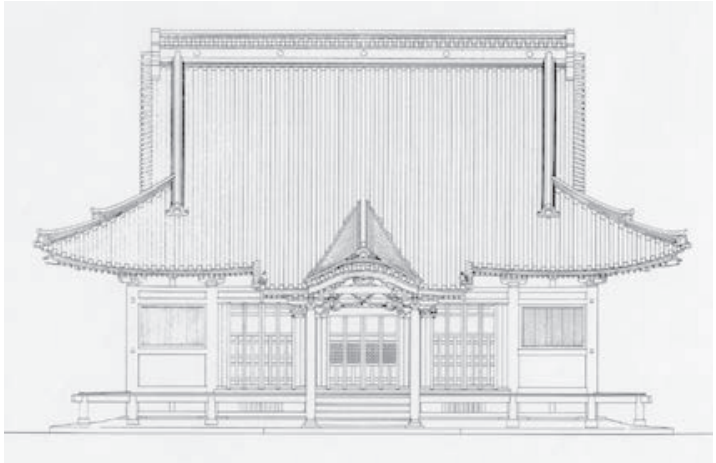

現状変更(9) 向拝を撤去し，木階段を石段に改める。

図 2 修理前正面図（出典:『国宝・重要文化財実測図集』）

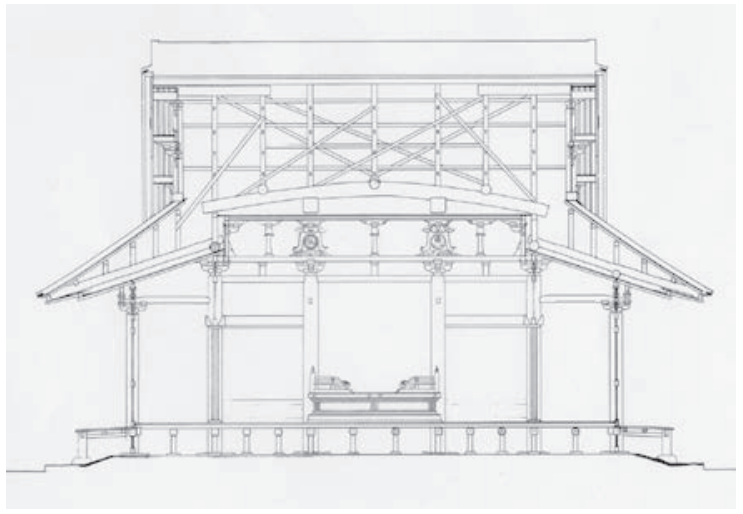

現状変更(8)内陣天井は斗栱と幕股によって高めて いるが，天井高を旧位置に下げる。

図 4 修理前桁行断面図（出典：『国宝・重要文化財実測図集』）
現状変更8 内陣の猿煩天井は, 鏡天井に改める。

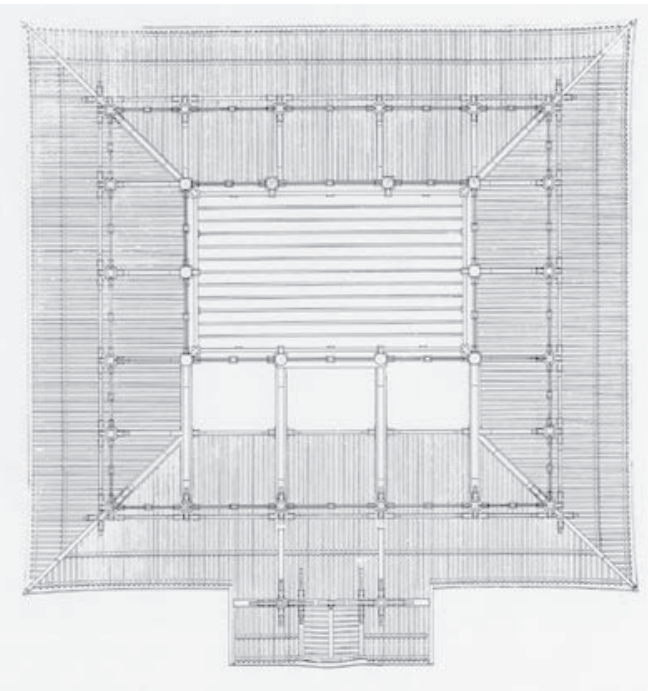

現状変更(7) 外陣の鏡天井は, 組入天井に改める。

図 6 修理前見上図（出典：『国宝・重要文化財実測図集』）

現状変更(1) 連子空は小脇壁を有する形式にする。

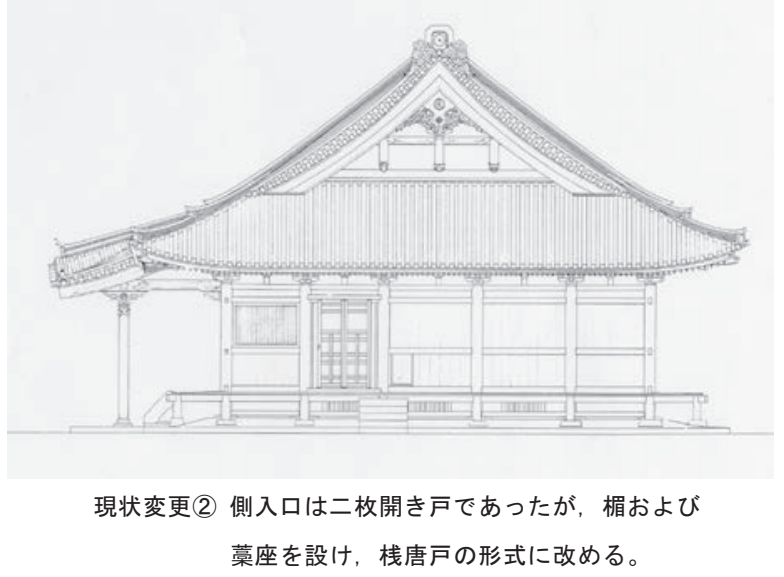

図 3 修理前東側面図（出典:『国宝・重要文化財実測図集』）

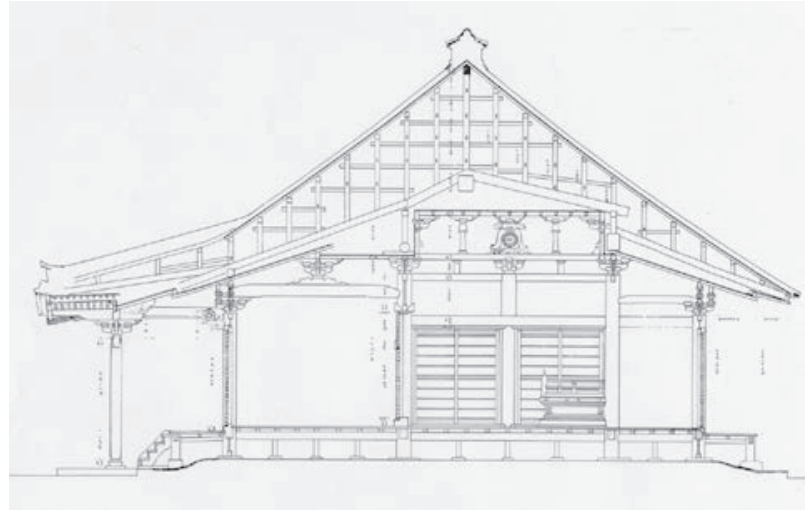

現状変更(4)内陣両入側境の各二間は内法長押, 敷居, 鴨居,

舞良戸引違を撤去し，楣を設けて柱間を開放する。

図 5 修理前梁行断面図（出典：『国宝・重要文化財実測図集』） 
以上，側廻りの飛貫，胴貫，足固貫の各貫成，連子空，縁側の高 さ, 扉の形式の変更が許可された。内部は内外陣境装置, 内陣両入 側境, 後陣境, 来迎柱, 外陣天井, 内陣天井の変更が許可された。 向扯は撤去され，木階段を石階段に変更することになった。

\section{4. 昭和修理前と現状変更}

\section{（1）昭和修理の現場事務}

「報告書」の「十，現場事務」は，「今回工事竣成シ実施工程表. 実施仕様書並二精算書. 寫䢐. 実測図. 竣成図. 拓本. 其八他必要 ノ書類」を文部省へ提出したとある。文部省へ提出した昭和修理に 関する書類には写真，実測図，竣成図，拓本が含まれていた。

図面については「平面．正面．側面．縦横断，見上図ノ実側及竣 成各一組」とあり，その他に「詳細。矩計. 規矩等」の図面が仕上 げられていた。奈良文化財研究所は, 平面図・正面図・側面図・横 断面図・縦断面図・見上図（縮尺 50 分の 1 ）の 6 枚と詳細図（縮 尺 10 分の 1 ）の 1 枚を保管し $\left.{ }^{19}\right) ， 7$ 枚の保存図は修理前の「実測 図」であり，文部省へ提出されていた実測図であった ${ }^{20)}$ 。竣成図で ある「修理竣工図」は，現存を確認することができない。摺拓本の 目録はすでに作成されていたが 21)，写真乾板の目録も刊行された ${ }^{22}$ 。

\section{（2）現状変更の検証}

「報告書」の「五. 各部ノ調查」は, 痕跡調查の所見を記述して おり，その所見は修理前の「実測図」を参照することで検討を加え ることができる（表 2 ・図 1 〜図 6 )。

「現状変更一」の連子空については, 修理前の小脇壁を確認する ことができないが (図 3 ), 竣工後は小脇壁を有する連子空になって いる。修理前の「側迴飛貫、胴貫、足固貫」の各貫成は, 「後補ノモ ノデ各貫穴习検スルニ後世一寸彫拡ゲテイルコトガ鰲痕ニヨッテ判 然サレテイル． 即チ元ノ貫八現頭貫全様ノ七寸デアッタノデアル」 とあり, 痕跡から 7 寸であった。現状変更では, 「側䞟飛貫、胴貫、 足固貫の各貫成を減じ」ということになったものと考えられる。「縁 を舊規に復せん」とあるが,「足固貫ノ成イヨ高メラレタ際ニ下バニ

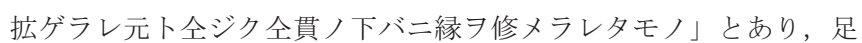
固貫の成を高めた際に縁が下げられていたが，現状変更によって足 固貫の成を減じたため, 縁の位置を高くしたものと考えられる。

「現状変更二」の修理前の側入口は二枚開き戸であり，上下に半 長押のような部材が取り付き, 軸穴を設けて装置されたと考えられ る (図 3 )。痕跡調查では葈座附であったことが判明し, 竣工後は楣 および莕座を設け，屝の形式を栈唐戸に変更している。

「現状変更三」の「内外陣界」の修理前は，大岡論文の「二、國 分寺本堂」の写真に掲載され (写真 1 ), 内外陣境の中央の間は二枚 折戸, 飛貫上が彫刻欄間であったことがわかる ${ }^{23)}$ 。「報告書」の「五. 各部ノ調查」の「内外陣境装置」には, 飛貫上の彫刻入欄間の框に 「寛文十二年一月吉日此方里物高松大工彦左衛門方里申候」の墨書 を発見したとあり, 内陣前面五間の間仕切装置は寛文年間のもので あることが明らかになった。竣工後は内外陣境の五間の建具が引違 格子戸，菱欄間に変更され，上部は真壁に改められている ${ }^{24 ） 。 ~}$

「現状変更四」の「内陣両側」の各二間の修理前は内法長押, 鴨 居, 敷居を設けた舞良戸引違であり, 内法長押の上部は真壁とみら れる (図 5 )。「報告書」の「五. 各部ノ調査」の「内陣両入側境」 は「内外陣境装置」と同様に「形式．仕ロヨリ寛文年間ノモノデア

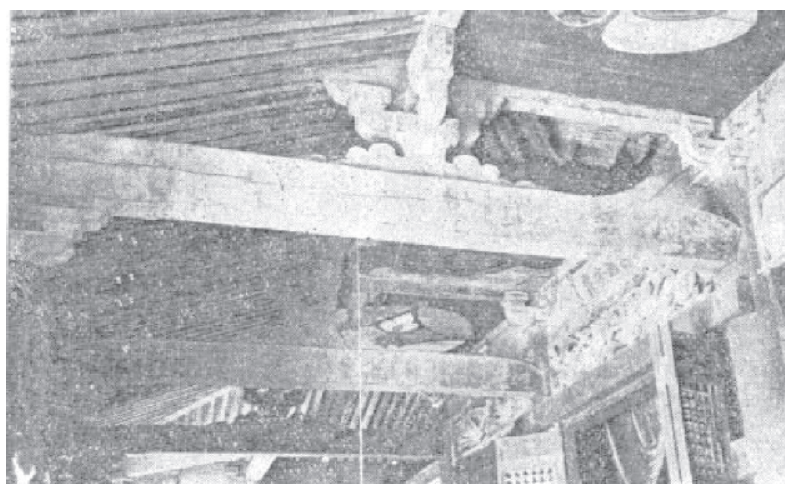

写真 1 讃岐国分寺本堂の昭和修理前の外陣（出典：大岡實, 四國路の旅一國分寺本堂一，畫説，第 67 号，1942)

ロウ」とあり，痕跡から寛文年間の改造と判断された。竣工後は内 法長押，鴨居ならびに敷居の建具装置を撤去し，楣より下方の柱面 には痕跡がなく，各柱間を開放した。楣の上は「柱面及飛貫下端に 壁間渡穴を存し」と壁であった痕跡が残され，真壁に復している ${ }^{25)}$ 。

「現状変更五」の修理前の「後陣」は，左右各一間が板嵌であった とみられる (図 1 )。「報告書」の「五. 各部ノ調査」の「後陣境」 は,「材質. 手法等ヨリ寛文年間修理ノモノト思八レ」とある。板嵌 は材質とその手法から寛文年間の改造と判断し，撤去することにな った。楣の上方の柱面, 繫貫, 繫虹梁などには壁間渡穴を設けた痕 跡があり, 竣工後は真壁に改めた。相より下方の柱面は痕跡がなく， 後陣の左右各一間を開放した ${ }^{26}$ )。

「現状変更六」の修理前の「内陣後柱」の来迎柱は，柱間が桁行 中央柱間より約 2 尺広くなっていた（図 1 )。竣工後は，来迎柱の柱 間が桁行中央柱間と同じ位置に変更されている 27$)$ 。来迎柱の移動に ついては,「来迎柱取付ケノ高欄八全形式ノ宝珠柱及伞半柱ヨ以テ建 テ高欄习補充シ」とあり,須弥壇の高欄を補充していたことになる。

「現状変更七」の外陣天井は，修理前が鏡天井である（図 6 ）。大 岡論文の「二、國分寺本堂」の写真をみると（写真 1 ), 修理前は外 陣の鏡天井に天井画が描かれていたことがうかがわれる 28)。天井組 子仕口穴は元にあった痕跡を残し，この痕跡が四方の天井桁に存し ていることから，竣工後は組入天井に変更された ${ }^{29}$ 。

「現状変更八」の内陣天井は修理前が猿煩天井とみられ（図 6 ), 出組の斗栱と蟇股を組み上げて天井を張っている（図 4$)$ 。「報告書」 の「四．破損状況」の「天井」には，「内陣ノ部分（桁行三間梁間二 間）近世異様ノ斗栱. 蟇股ヨ以テ引キ上ゲテ棹縁天井ニ改メラレタ モノ」と記される。「五. 各部ノ調査」の「内陣天井」には, 「元ノ 天井迴縁ノ上ニ特殊ノ斗栱ヨ彩色习施シ組上ゲ猿煩天井ヨ設ケテア ル彩色八寛文年間施サレルモノト所々二墨書ガアリ」と記される。 寛文年間に内陣天井は，旧天井の迴縁の上の斗栱に彩色を施し，蟇 股をもって天井を引き上げ，猿煩天井に改造していた。竣工後は， 内陣天井が痕跡にもとづいて鏡天井に変更された ${ }^{30}$ )。

「現状変更九」の修理前の向拝は,「解体修理前の本堂」の写真か ら確認できるが 31 , , 向扯一間, 唐破風付であり, 向扯の虹梁の上に 3 つの蟇股が置かれていた（図 2 )。「報告書」の「五. 各部ノ調査」 の「向拝部」は，蟇股下に「寛文九年西季八月十四日後藤氏盛継形 見敬白」の墨書を発見したとある。向扯の全体の形式は同時期のも のであることを明らかにし，寛文年間に新たに附加したものとみら 
れている。向拝の屋根と本堂の取り合いは, 谷になって水取りが悪 しく, 保存上障害があるために撤去することになった。修理前は木 階段が 4 段であったが (図 2 ), 向拝の撤去後は木階段が腐朽し易い

\section{ことにより，石段に改めている。}

\section{(3) 建築形式の類例調査}

連子空，側入口の栈唐戸，内陣境格子戸ならびに菱欄間の現状変 更では，類例調查を実施していたことが明らかになる（表 2 ）。「報 告書」の「七. 修理概要」は連子空について「國寶石手寺其他當時 代ノモノヨ調查研究ノ上製作シ」とあり, 石手寺など同時代のもの を調查研究して製作した。側入口の栈唐戸, 内陣境格子戸および菱 欄間は, 奈良県の「法隆寺上御堂全聖霊院」「室生寺本堂」「不退寺 本堂」, 広島県の「浄土寺本堂」「明王院本堂」を比較研究し, 製作 して装置していた。

「大棟瓦張リ」は, 「近年ノモノデ不調和デアルカラ熨斗瓦積二改 メ鬼瓦ノ新補ノモノ八建造物全時代ノモノニ模造スルコト」とある。 修理前の屋根の頂部にある大棟は箱棟形瓦張りとみられ(図 2), 「近 年ノモノデ不調和デアル」「異例ノモノ」という理由で, 竣工後は尉 斗積みに改めている。鬼瓦については「補修ノ分八法隆寺夢殿ノモ ノヨ模造シ」とあり，その補修は法隆寺夢殿を模造していた。

\section{5. 寛文年間の改造と昭和修理における未変更}

\section{（1）昭和修理にみる寛文年間の改造}

讃岐国分寺本堂は屋根勾配, 妻飾, 内陣天井, 須弥壇と㕌子, 向 拝が近世の改造であることが一般に認められてきた。寛文年間の改 造については, 「報告書」の「三. 沿革」に「向拝ノ附加. 来迎柱. 須弥壇ノ新補. 天井ノ引上ゲ. 屋蓋. 妻飾ノ改造ニ迄及ンデオリ」 とあり, 来迎柱も近世の改造であった。昭和修理では向拝, 来迎柱, 内陣天井が現状変更された。

「報告書」の「四. 破損状況」には小屋組, 妻飾, 須弥壇と厨子 が近世の改造という注目すべき記載があった。「小屋組」は「近世修 理ノ際組ミ改メラレタモノ」と記されており, 近世に小屋組が改造 されていた。「妻飾」は「近世ノ修補二成リ」とあり, 近世の改作で あった。「須弥壇及厨子」は「両者八近世ノ製作デアッテ」とあり, 近世に須弥壇と㕌子を設けたことが認められていた。

\section{（2）現状変更されなかった箇所}

「報告書」の「九. 工事仕様」をみると,「小屋組」は「大体現在 ノ構造习踏襲スル」とあり, 近世の改造であることが確認され, 当 初形式と異なることが明らかであっても現状が踏襲されていた。

妻飾は「四. 破損状況」に「破風板. 懸魚. 結綿鬼面. 壁板八破 損風化減甚シク其ノ他ノ部分腐朽. 破損八僅少デアッタ」と記され る。「九. 工事仕様」は「大体損傷少ク」とあって, 「新補ノモノ八 在来形式二倣七仕拵へ旧材ノ取繥七モノト共二漸次組立テ或八大釷 ニテ取ケ」と記される。妻飾は近世の改造であったが，損傷が少な かったことは, 復原しなかった一因としてあげられる。妻飾の新補 は，在来形式に倣って旧材を取り繥って修理された。

須弥壇と厨子は,「九. 工事仕様」に「殆ド損傷ナキ」とある。破 損が認めらなかったことが, 復原しなかった一因と考えられ, 現状 の通りになった。本尊の木造千手観音立像（重要文化財）は影子に 安置され, 平安後期の作とされる 32 )。本尊と本堂の建立年代は合致 しないが, 本尊は現本堂の建立当初に安置されたことが示唆されて
いる ${ }^{33)}$ 。㕌子は，寛文年間に本尊を安置するために新たに設けたも のと考えられている。

\section{6. まとめ}

讃岐国分寺本堂は, 昭和 13 年 9 月の大暴風雨によって屋根の一 部が破損した。解体修理は昭和 16 年 2 月に起工し, 昭和 18 年 8 月 に竣工していた。昭和修理は部材に刻まれた改造の痕跡を克明に調 査し，発見物によって創建以来の沿革，寛文年間における増改築を 明らかにした。「報告書」は，昭和修理における方針とその内容をま とめた貴重な資料である。本論では現状変更の要旨と理由を明らか にし, 修理前実測図を基礎資料にどのように変更したかを検討した。 第一に，昭和修理では建立年代が判明しなかったが，建築形式か ら鎌倉後期と考えられ，文化年間の平瓦に刻印された瓦笓文字は， 本堂が天正年間の兵火を免れた旧講堂であることを伝えている。

第二に, 本堂は天平時代の講堂跡の礎石を再用し, 規模を改めて 建立された。床下地盤の調查の成果にもとづいて, 建立当初は土間 に計画されたが，床張りに改められたものと考えられている。

第三に, 外部は側迴りの飛貫, 胴貫, 足固貫の各貫成, 連子空, 縁側の高さを現状変更した。現状変更は後世の改変の痕跡を手がか りにして，当初の形式に復原したものと考えられる。

第四に，向拝は墨書が発見され，寛文年間に附加したことが明ら かとなった。現状変更では向帱を撤去し, 木階段を石段に改めた。

第五に, 内部は内外陣境装置に寛文年間の墨書が発見され，飛貫 上に欄間彫刻を設けて間仕切装置を改造したことが明らかになった。 内陣は寛文年間に斗栱と蟇股によって引き上げた猿煩天井を張り, 内陣両入側境と後陣境を改造していた。現状変更は内外陣境装置, 内陣両入側境, 後陣境, 来迎柱, 外陣天井, 内陣天井を後世の改変 の痕跡を手がかりに，当初の形式に復原したと考えられる。

第六に, 連子空，側入口の栈唐戸，内外陣境の格子戸と菱欄間の 現状変更には，類例調查が実施されていた。

第七に,近世に改造された妻飾は, 旧材を取り繕って修理された。 須弥壇と厨子は損傷がみられず，近世の新設であっても現状のまま となった。国宝保存法時代の修理は, 創建時の屋根の形態の復原を 重視していた ${ }^{34)}$ 。小屋組は近世の改造が明らかになっても現状が踏 襲され，屋根勾配は建立当初と異なるものとなった。

以上，讃岐国分寺本堂は建立年代が鎌倉後期ではあるが，昭和修 理において解体修理が起工し, 現状変更が許可されていた。本論で は昭和修理に関する資料を検討し，遺構は現状変更によって建立当 初の形式に復原された箇所があるが，後世の改造が判明しながらも 現状の通りとなった箇所を明らかにすることができた。最後に建立 当初の建築形式の解明については, 今後の課題としたい。

\section{謝 辞}

讃岐国分寺本堂の資料所在は, 高松市教育委員会文化財課藤井雄 三副部長にご教示をうけ，高松市歴史資料館の堀純子氏のご協力を えました。大岡實博士文庫の閲覧は, 安田徹也氏に便宜をはかって いただいた。ここに記して深謝いたします。

本研究は, 平成 $21 \sim 23$ 年度科学研究費補助金 (基盤研究(C)）「四 国における戦前期の古社寺建造物の修理に関寸る研究」（研究代表 者: 三浦要一, 課題番号：21560669）の成果の一部である。 
注

1 ）文化庁文化財保護部史跡研究会監修: 図説 日本の史跡 第 5 巻 古代 2 , 同朋舎, pp. $244 \sim 245,1991$

2 ) 文化財建造物保存技術協会編集: 国宝・重要文化財建造物官報告示, p.11, 1996

3 ) 文化財建造物保存技術協会編集: 資料旧国宝建造物指定説明, p. 55, 1982

4）文化庁編集：国宝・重要文化財建造物目録，第一法規，p.543，2000

5 ) 文化庁編集 : 建造物要覧 昭和 60 年度, p. 57,1985

6 ) 文化庁監修: 国宝・重要文化財大全 11 建造物（上巻），毎日新聞社， p.98, 1998

7 ) 山岸常人：古代寺院の再興と律衆 讃岐国分寺本堂, 朝日百科 国宝と 歴史の旅 下，朝日新聞社，pp.46〜 52, 2001

8 ）鈴木嘉吉：四国の古建築，佛教藝術， 53 号，pp.18～19, 1964

9 ) 前掲 7 )

10）青柳憲昌：国宝保存法時代の建造物修理に示された保存の概念, 日本建 築学会計画系論文集，第 620 号，pp.235 242，2007.10

11）浅野 清：古代建築の修理改造のあり方に関寸る歴史的考察, 橿原考古 学研究所論集 第五, 吉川弘文館, pp.327 340, 1979。岡田英男：建造 物修理初期の批判と現在の施工上の問題点, 日本建築の構造と技法 [下], 思文閣出版，pp. $143 \sim 155 ， 2005$

12) 三浦要一: 豊楽寺薬師堂の明治修理, 日本建築学会計画系論文集, 第 617 号, pp.127 134, 2007. 7 ; 竹林寺本堂の建立年代と明治移築, 2011 年 度日本建築学会関東支部研究報告集 審査付き研究報告集, 7, pp.161 164,2012

13) 瀬戸内海歴史民俗資料館蔵 (歴史収蔵資料目録十三 松浦正一文庫目録, p.38，1989）。『さぬき国分寺町誌』（国分寺町誌編纂委員会編集，p.280， 2005）がすでに紹介されている。
14）現在，讃岐国分寺本堂は内部の遺構調査が許可されていないが，以下の 報告をおこなっている。三浦要一: 讃岐国分寺本堂の昭和修理（Ｉ）（II）， 2009 年度日本建築学会関東支部研究報告集 II, pp. 537 544, 2010

15）川崎市立日本民家園蔵

16）前掲 13），pp.761～762

17）前掲 7)

18）忍冬会 : 清交，第 19 号, pp.29〜38, 1942

19）奈良文化財研究所編集: 国宝・重要文化財建造物保存図目録, p.112, 2003

20）文化庁編集：国宝・重要文化財（建造物）実測図集（香川県 その 2 ）, pp.151 157, 1973

21）奈良文化財研究所編集: 国宝・重要文化財建造物摺拓本等目録・下, pp.232 〜233, 2001

22）奈良文化財研究所編集：国宝・重要文化財建造物写真乾板目録 V, pp.234 236, 2012

23）大岡 實: 四國路の旅－國分寺本堂一, 畫説，第 67 号, pp.501 509, 東京美術研究所, 1942

24）前掲 7 )

25）前掲 7 )

26）前掲 6 ）， p.669。前掲 7)

27）前掲 6 )， p.669。前掲 7 )

28）前掲 23）

29）前掲 7)

30）前掲 7 )

31）前掲 13），p.760

32）前掲 13），pp.741～742

33）前掲 23）

34）前掲 10

（2012年 6 月 10 日原稿受理， 2012年 8 月 3 日採用決定） 